\title{
Comparative Study of MPPT Methods for Solar PV Driven Induction Motor Load
}

\author{
Rupendra Kumar Pachauri \\ Electrical Engineering Department \\ School of Engineering \\ Gautam Buddha University, Greater Noida, India
}

\author{
Yogesh K. Chauhan \\ Electrical Engineering Department \\ School of Engineering \\ Gautam Buddha University, Greater Noida, India
}

\begin{abstract}
The performance of intelligent maximum power point tracking (MPPT) such as Fuzzy logic controller (FLC) and artificial neural network (ANN) are investigated, and compared with traditional constant voltage (CVC), Perturb \& observed (P\&O) and Incremental conductance (IC) MPPT methods to achieve maximum power point (MPP) through PV system, in this paper. For transient analysis of MPPT assisted photovoltaic (PV) system powered to the induction motor (IM) in various applications. The system performance is investigated for different irradiation conditions in terms of voltage, current, power and rotor speed response. The detailed study is carried on advantages of advance MPPT techniques over the traditional MPPT techniques. The modeling of solar PV system and considered MPPT techniques have been done in MATLAB/ Simulink environment.
\end{abstract}

\section{Keywords}

Artificial neural network, Fuzzy logic controller, Maximum power point tracking, Perturb \& observe, Photovoltaic systems, Renewable energy.

\section{INTRODUCTION}

The electrical energy demand is increasing day-by-day due to domestic and commercial applications [1]. Today, the potential of generated electric power is very low and also majorly dependent on fossil fuels e.g. diesel, petrol and coal etc., but this generated power is not insufficient to meet the demand of required power [2]. To fulfill the demand power, an interest is creating force to explore more sustainable and reliable energy sources for power generation such as PV system, wind turbine (WT), fuel cell (FC), bio-fuel etc.

The energy conversion efficiency of PV system is very low approximately $30-40 \%[3,4]$. To extract maximum power from PV system, the maximum power point tracking (MPPT) techniques e.g. constant voltage control (CVC), incremental conductance (IC), perturb \& observe (P\&O), fuzzy logic control (FLC), artificial neural network (ANN) techniques are investigated and found in literature.

\section{LITERATURE REVIEW}

In [5], the authors gave a concept on MPPT techniques e.g. open circuit (OC) voltage, short circuit (SC) current, $\mathrm{P} \& \mathrm{O}$ and IC and compared the transient analysis of various MPPT techniques. The authors designed different MPPT techniques e.g. CVC, P\&O, IC, fractional short circuit for transient analysis under various operating conditions [6]. The authors of [7] investigated the MPPT technique e.g. P\&O, IC, hill climbing and advanced MPPT techniques as FLC, ANN for the partial shading condition. The authors of [8-10] gave a comprehensive review of MPPT algorithms. The authors of [11] discussed fuzzy logic based MPPT assisted PV system for hybrid power generation. The authors [12], reviewed the various MPPT techniques, basically this paper can be considered as a bench mark for future work. The overview of MPPT techniques for PV system is given in [13]. For the purpose of transient analysis and comparative study, the IC and P\&O MPPT techniques are considered. In [14], the author is focused on the review of various MPPT techniques such as, $\mathrm{P} \& \mathrm{O}$ and IC under changing environmental conditions. In [15-16], the authors compared various MPPT techniques e.g. CVC, short circuit pulse method, open voltage method, $\mathrm{P} \& \mathrm{O}$ and modified $\mathrm{P} \& \mathrm{O}$, no focused on the advance MPPT techniques such as Fuzzy logic and ANN based. In [17], the authors proposed a concept on P\&O MPPT algorithm and compared with another MPPT techniques. The authors in [18], reported a review of MPPT techniques for solar PV systems, but the transient analysis and modeling of MPPT techniques are not reported. In [19], the authors proposed MPPT techniques such as IC, FLC and ANN MPPT techniques.

\section{SYSTEM DESCRIPTION}

The complete system consists of mainly three parts (a) PV system (b) MPPT methods (i) Constant voltage control (ii) Incremental conductance (iii) Perturb \& Observe (iv) Fuzzy logic controller (v) Artificial neural network MPPT methods (c) DC-DC boost converter and induction motor. The schematic diagram of the proposed system is shown in Fig. 1 as,

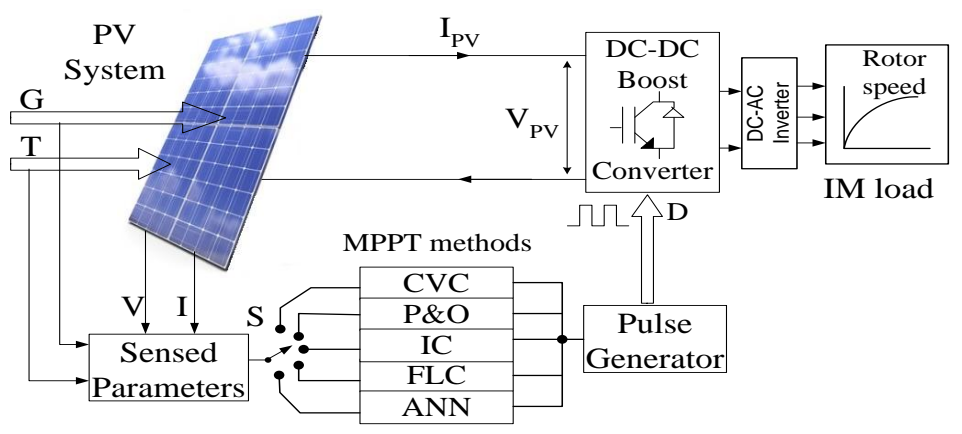

Fig 1: Schematic diagram of various MPPT methods assisted PV system driven IM 


\section{PV SYSTEM MODELING}

The P-V and I-V characteristics of PV cell are non-linear. The most referred electrical equivalent circuit as shown in Fig. 2 as,

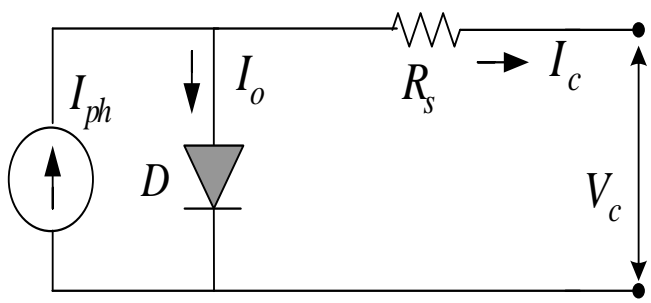

Fig 2: Electrical Equivalent circuit of PV cell

The $V_{C}$ (PV cell voltage) is dependent on the load current and the solar temperature, shown in Eq. (1) as,

$V_{C}=\frac{A k T_{C}}{e} \ln \left(\frac{I_{p h}+I_{o}-I_{c}}{I_{o}}\right)-R_{s} I_{c}$

$C_{T V}$ and $C_{T I}$ respectively using Eq. (2) and (3) [20-22] as,

$C_{T V}=1+\beta\left(T_{a}-T_{x}\right)$

$C_{T I}=1+\frac{\gamma_{T}}{S_{C}}\left(T_{x}-T_{a}\right)$

$C_{S V}$ and $C_{S I}$, which are the correction factors for changes in $V_{C}$ and $I_{p h}$, are expressed in Eq. (4) and (5) as,

$C_{S V}=1+\beta_{T} \alpha_{S}\left(S_{x}-S_{c}\right)$

$C_{S I}=1+\frac{1}{S_{c}}\left(S_{x}-S_{c}\right)$

Using correction factors $C_{T V}, C_{T I}, C_{S V}$ and $C_{S I}$, the new values of $C_{S I}$ and $I_{p h x}$ are expressed by Eq. (6) and (7) [23]as,

$V_{c x}=C_{T V} C_{S V} V_{C}$

$I_{p h x}=C_{T I} C_{S I} I_{p h}$

Using Eq. (1)-(7) the mathematical model of PV cell is developed for the analysis of the various MPPT methods. For the MATLAB/Simulink modelling of PV system and validation, a commercial model Suntech Power STP260$24 / \mathrm{Vb}$ (mfd. by Suntech) is considered, whose specifications are summarized in Table 1 as,

Table 1. Specifications of Suntech Power STP260-24/Vb module [24]

\begin{tabular}{lr}
\hline \multicolumn{1}{c}{ Parameter } & \multicolumn{1}{c}{ Value } \\
\hline Nominal peak power, $P_{m p}$ & $260 \mathrm{~W}$ \\
Nominal voltage, $V_{p h}$ & $34.8 \mathrm{~V}$ \\
Nominal current, $I_{p h}$ & $7.47 \mathrm{~A}$ \\
Short circuit voltage, $V$ & $44 \mathrm{~V}$
\end{tabular}

\begin{tabular}{lr} 
Short circuit current, $A$ & $8.09 \mathrm{~A}$ \\
Maximum power, $P_{m p}$ & $260 \mathrm{~W}$ \\
Series resistance, $R_{s}$ & $0.037 \Omega$ \\
Saturation current, $I_{o}$ & $1.1753 \times 10^{-8} \mathrm{~A}$ \\
Operating temperature, $T_{c}$ & $25 \mathrm{C}$ \\
Irradiation level, $S_{x}$ & $1000 \mathrm{~W} / \mathrm{m}^{2}$ \\
\hline
\end{tabular}

\section{MPPT TRACKING METHODS}

To obtain maximum power from PV module, various electrical and mechanical MPPT methods are proposed. In mechanical methods, the orientation of the PV panel is adjusted with the pre-estimated angle throughout the day for tracking the sun direction manually. In electrical tracking method, the maximum power point (MPP) is tracked on P-V curve of the system by the help of power electronics interface. Conventional tracking methods use the sensed data of PV system such as voltage, current, temperature and solar irradiation to track the MPP.

\subsection{CVC Based MPPT Method}

This method is forced the voltage across the PV output voltage held at a constant value, normally specified to ensure the maximum power transfer to load. In this method a single voltage sensor is required and it is introduced by simple implementation and low installation cost. The CVC method is perhaps the simplest MPPT algorithm. This algorithm can be implemented without a digital controller [25]. The limitation of the algorithm is that the MPP depends on the specific solar panel type. The schematic diagram of CVC based MPPT algorithm is exposed in Fig. 3 as,

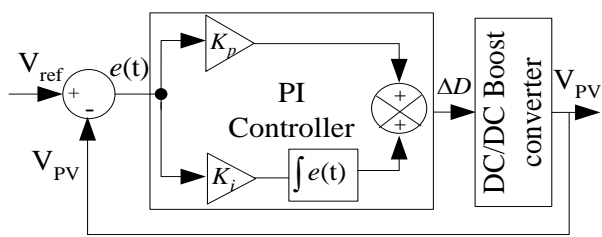

Fig. 3: Block diagram of CVC MPPT method

The proportional-integral control equations can be expressed using Eq. (8) as,

$$
\Delta D=K_{p} e(t)+K_{i} \int e(t) d t
$$

Where, $K_{p}$ - proportional gain and $K_{i}$ - integral gains to be adjusted for the desired output from the PV system.

\subsection{P\&O Based MPPT Method}

In this method, the voltage of the PV system is considered as a reference signal. The aim of this MPPT is to force the reference voltage of the PV system to maximum voltage $\left(V_{m p p}\right)$, which causes the instantaneous PV voltage to track $V_{m p p}$. This is done by applying small and constant perturbations to the PV voltage a step-by-step. After each perturbation the variation in power $(\mathrm{dP})$ is measured [26]. A positive value of $\mathrm{dP}$ indicates that output power will approach MPP. So, a perturbation of positive sign is fed to the PV voltage in the next stage. On the other hand, if the value of $\mathrm{dP}$ is found negative, negative sign perturbation is applied [27]. These steps are repeatedly performed until the MPP of the system is reached where $\mathrm{dP}$ is equal to zero or maximum 
condition. The steps involved in this method are depicted with the help of flowchart shown in Fig. 4 as,

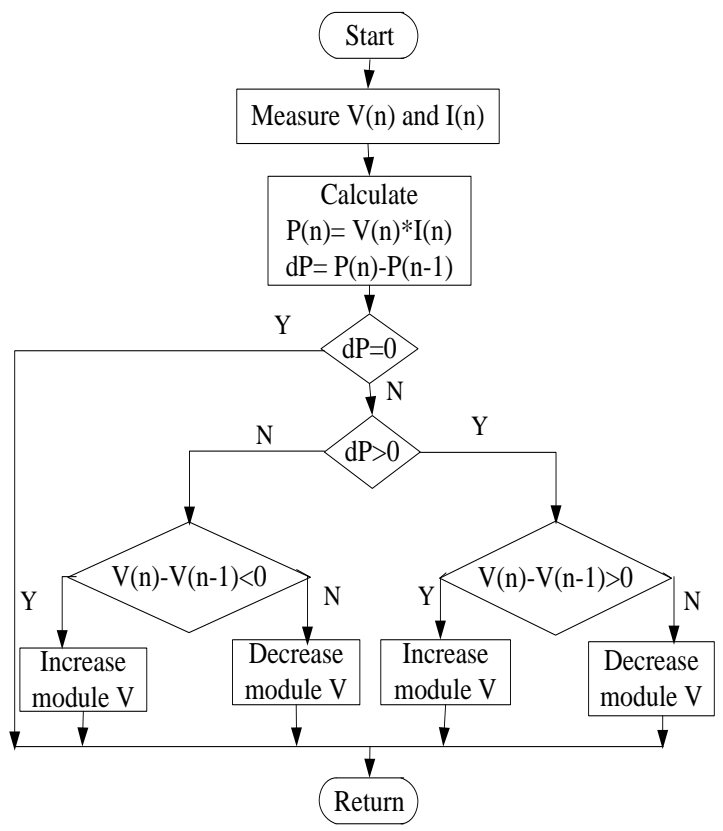

Fig 4: Flowchart of P\&O MPPT method

\subsection{IC Based Method}

This MPPT method is based on principle that the slope of the power curve of the PV system at the MPP is zero, positive when the power is less than MPP and negative when the output power is greater than the MPP [28]. It can be evaluated by differentiating the power of the PV w. r. t PV voltage and equal it to zero, as expressed in Eq. (10) \& (11) as,

$\frac{d P}{d V}=I+V \frac{d I}{d V}=0$

$\frac{d I}{d V} \cong \frac{\Delta I}{\Delta V}=\frac{-I_{M P P}}{V_{M P P}}$

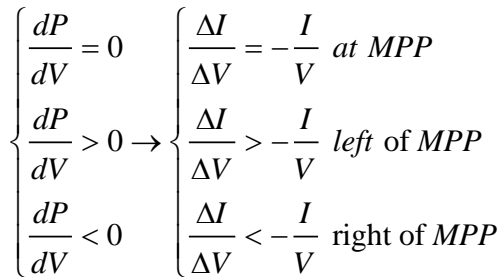

Hence, it can be experienced whether the PV system is operating at or missing from the MPP [29]. Three derivative conditions are expressed in above Eq. (12).

\subsection{FLC Based MPPT Method}

Recently, FLC are introduced for MPPT in the PV system. The main parts of a FL controller are fuzzification, inference; rule base and defuzzification are shown in Fig. 6 as,

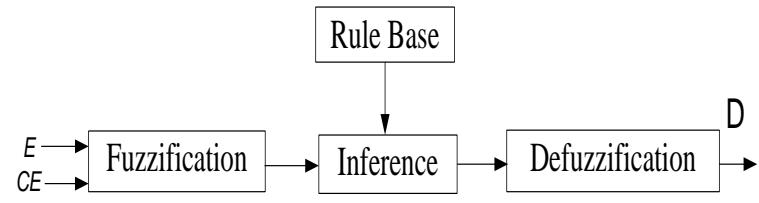

Fig 6: Block diagram of FLC based MPPT method
In fuzzification step, the input crisp variables are converted into linguistic variables according to the input membership functions [30-31]. In inference step, also known as decisionmaking step, If-Then specified rules identify the behaviour of the controller. The rules in this step are stated as linguistic variables denoted by fuzzy sets. The two inputs i.e. error $(e)$ and change of error (ce) are defined as,

$$
\begin{aligned}
& E(m)=\frac{P_{p v}(m)-P_{p v}(\mathrm{~m}-1)}{V_{p v}(\mathrm{~m})-V_{p v}(\mathrm{~m}-1)} \\
& C E(m)=E(m)-E(m-1)
\end{aligned}
$$

Where, $P_{P V}$ is the power of PV module. The fuzzy inference is fed using Mamdani's method. Here, defuzzification uses center of gravity method to obtain the output which is the duty cycle of DC/DC boost converter [32].

\subsection{ANN Based MPPT Method}

Many developments are made in the field of ANN controllers. The environmental parameters e.g. irradiation and temperature are applied to ANN as input. At the output stage a duty cycle is generated for a DC/DC boost converter which drives the PV voltage to optimal voltage $[33,34]$. The input and output are expressed in Eq. (16) \& (17) as,

$$
\begin{aligned}
& y_{j}^{h}=f\left(\sum_{i=1}^{N} W_{i j} X_{i}+\theta_{j}^{h}\right) \\
& y_{k}^{o}=f\left(\sum_{j=1}^{N} W_{k j} Y_{j}^{h}+\theta_{k}^{o}\right)
\end{aligned}
$$

Where, $W_{j i}$ and $W_{k j}$ are weights. $\theta_{j}^{h}$ and $\theta_{k}^{o}$ are the bias values. $X_{i}$ and $Y_{j}^{h}$ are the signal values for input and output lines.

\section{RESULTS AND DISCUSSION}

\subsection{Steady State Analysis}

The designed PV module was implemented with various designed MPPT methods to study their response and MPP tracking efficiency. The P-V and I-V curves of the PV system achieved from the above designed PV module at different solar irradiation conditions is shown in Figure 9(a)-(b) as,

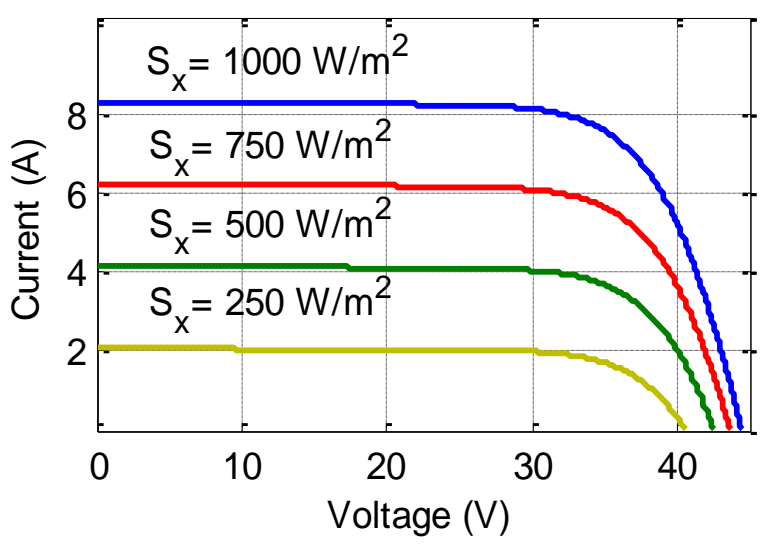

(a) I-V curve of PV system 


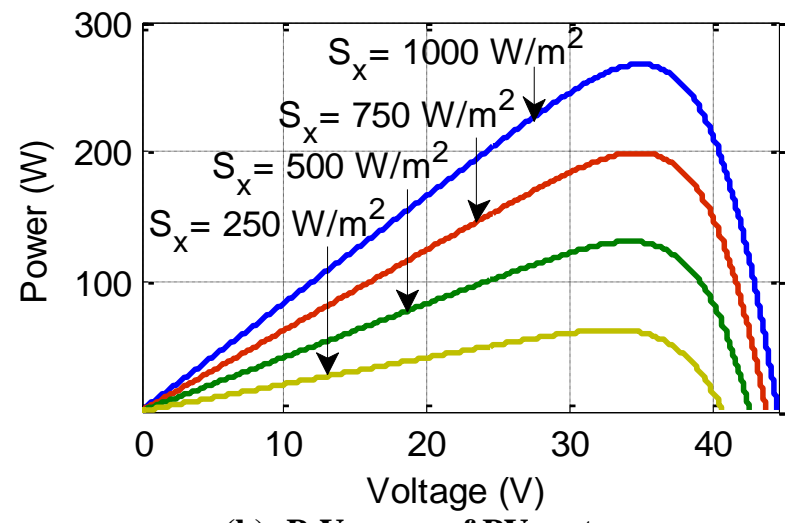

(b) P-V curve of PV system

Fig. 9(a)-(b): I-V and P-V curves of PV system at different environmental conditions

The output current, voltage and power of the designed PV system without any MPPT techniques under standard test conditions (STC) are shown in Fig. 10 as,

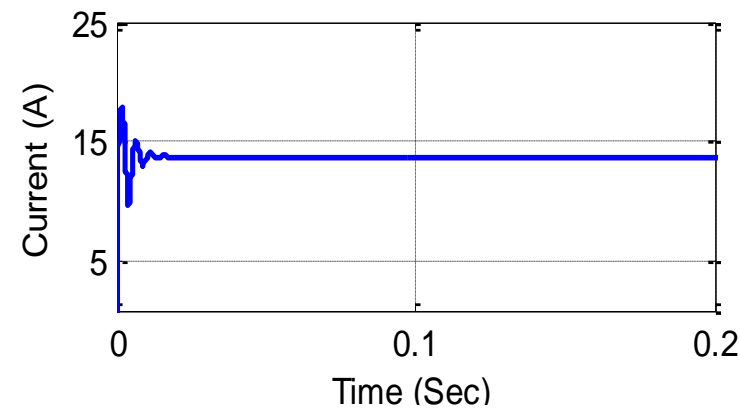

(a) Current (A)

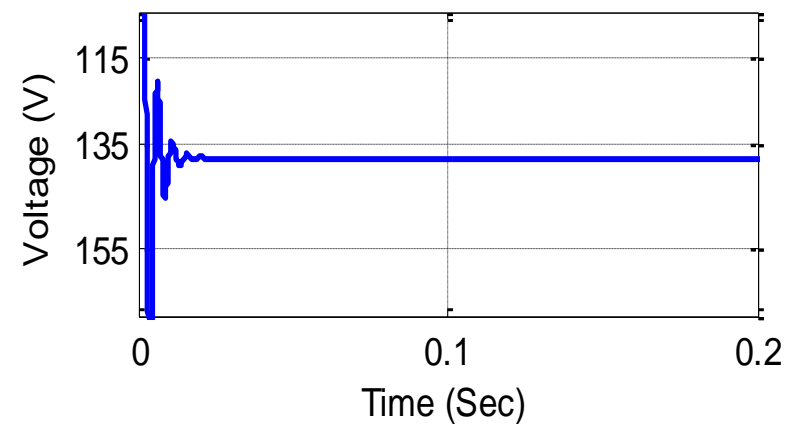

(b) Voltage (V)

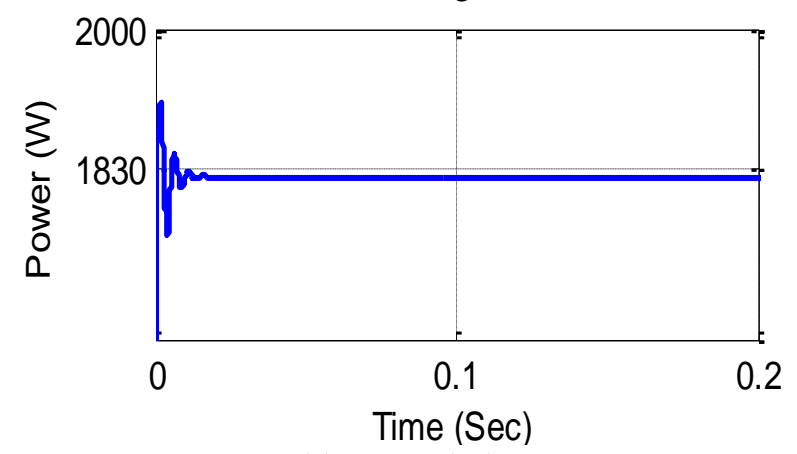

(c) Power (W)

Fig 10: Voltage, current, power of PV system under STC

\subsection{Transients of MPPT Methods Assisted Solar PV Power Driven IM System}

For transient analysis, the solar irradiation is varied in the range of $400-1000 \mathrm{~W} / \mathrm{m}^{2}$ in random discrete steps at $25^{\circ} \mathrm{C}$ for all implemented MPPT methods assisted solar PV power driven IM is depicted for each MPPT technique. For the analysis of this proposed system, CVC, PO, IC, FLC and ANN based MPPT techniques are simulated. The considered solar irradiation and voltage, current, power and rotor speed of IM is shown in Fig. 11-15.

In Fig. 11, the dynamic response of FLC MPPT assisted PV system under variable irradiation levels from $400-1000 \mathrm{~W} / \mathrm{m}^{2}$ various steps. At time $0-2 \mathrm{Sec}$. the irradiations level is 600 $\mathrm{W} / \mathrm{m}^{2}$, the PV voltage, current and power are $123 \mathrm{~V}, 8.17 \mathrm{~A}$ and $1006.11 \mathrm{~W}$ respectively. It is observed that less time is taken to reach rated speed of IM in comparison other MPPT techniques assisted system is $0.53 \mathrm{Sec}$. Now the irradiation level is raised up to $800 \mathrm{~W} / \mathrm{m}^{2}$, so the resultant voltage, current and power increased gradually increased at $127 \mathrm{~V}, 11.24 \mathrm{~A}$ and $1428.21 \mathrm{~W}$. Now the irradiation level is increased to $1000 \mathrm{~W} / \mathrm{m}^{2}$ at $3 \mathrm{Sec}$, the voltage, current and power are $131 \mathrm{~V}$, $13.93 \mathrm{~A}$ and $1825.91 \mathrm{~W}$. Now the irradiation is decreased at $400 \mathrm{~W} / \mathrm{m}^{2}$, the voltage, current and power is calculated as $115 \mathrm{~V}, 5.84 \mathrm{~A}$ and $672.09 \mathrm{~W}$ respectively. Furthermore, the irradiation levels are repeated in various steps, so the transient response of voltage, current and power are same as previous satisfactory results.
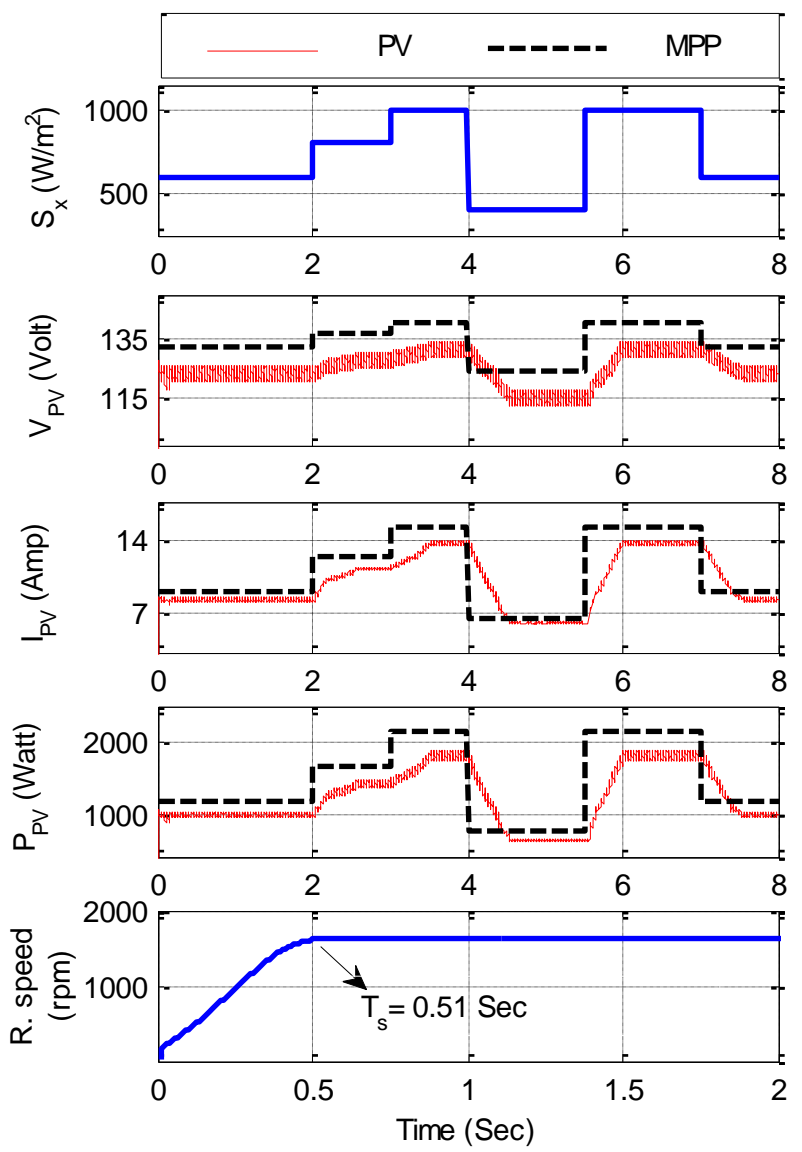

Fig 11: Dynamic response of CVC MPPT assisted PV system under variable irradiation conditions 
In Fig. 12, the dynamic response of P\&O MPPT assisted PV system under variable irradiation levels from $400-1000 \mathrm{~W} / \mathrm{m}^{2}$. Initially at time $0-2 \mathrm{Sec}$. the irradiations level is kept 600 $\mathrm{W} / \mathrm{m}^{2}$, the PV voltage, current and power are $125 \mathrm{~V}, 8.67 \mathrm{~A}$ and $1083 \mathrm{~W}$ respectively. It is observed that the rated rotor speed of IM is settled at $0.47 \mathrm{Sec}$. Now the irradiation level is raised up to $800 \mathrm{~W} / \mathrm{m}^{2}$ for next $1 \mathrm{Sec}$., the voltage, current and power increased gradually and found $129 \mathrm{~V}, 11.926 \mathrm{~A}$ and $1538 \mathrm{~W}$.Now the irradiation level is increased to $1000 \mathrm{~W} / \mathrm{m}^{2}$ at $3 \mathrm{Sec}$., the voltage, current and power are $133 \mathrm{~V}, 14.788 \mathrm{~A}$ and $1966.9 \mathrm{~W}$. Now the irradiation is decreased at $400 \mathrm{~W} / \mathrm{m}^{2}$, the voltage, current and power is calculated as $115 \mathrm{~V}, 5.84 \mathrm{~A}$ and $724 \mathrm{~W}$ respectively. Furthermore, the irradiation levels are repeated in various steps, so the transient response of voltage, current and power are same as previous satisfactory results. It is observed that the current is very close to its maximum value.
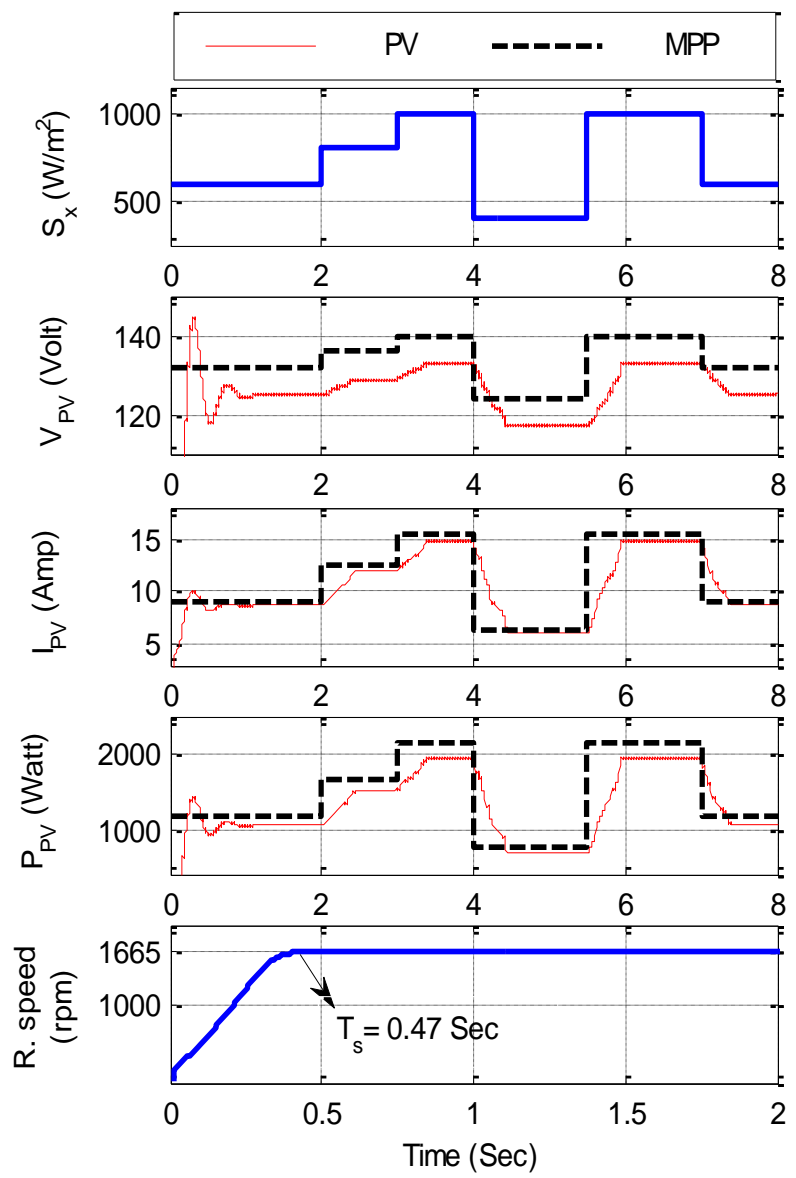

Fig 12: Dynamic response of P\&O MPPT assisted PV system under variable irradiation conditions

In Fig. 13, the dynamic response of IC MPPT assisted PV system under variable irradiation levels from $400-1000 \mathrm{~W} / \mathrm{m}^{2}$. Initially at time $0-2 \mathrm{Sec}$. the irradiations level is kept 600 $\mathrm{W} / \mathrm{m}^{2}$, the PV voltage, current and power are $126 \mathrm{~V}, 9.02 \mathrm{~A}$ and $1137 \mathrm{~W}$ respectively. It is observed that the rated rotor speed of IM is settled at $0.33 \mathrm{Sec}$. Now the irradiation level is raised up to $800 \mathrm{~W} / \mathrm{m}^{2}$, so the resultant voltage, current and power increased gradually increased at $130 \mathrm{~V}, 12.41 \mathrm{~A}$ and $1614.2 \mathrm{~W}$. Now the irradiation level is increased to $1000 \mathrm{~W} / \mathrm{m}^{2}$ at $3 \mathrm{Sec}$, the voltage, current and power are $134 \mathrm{~V}, 15.4 \mathrm{~A}$ and 2063.7W. Now the irradiation is decreased at $400 \mathrm{~W} / \mathrm{m}^{2}$, the voltage, current and power is calculated as $118 \mathrm{~V}, 6.437 \mathrm{~A}$ and
$759.634 \mathrm{~W}$ respectively. Furthermore, the irradiation levels are repeated in various steps, so the transient response of voltage, current and power are same as previous satisfactory results. It is observed that the current is close to its maximum value. The transient disturbances are very high in case voltage.
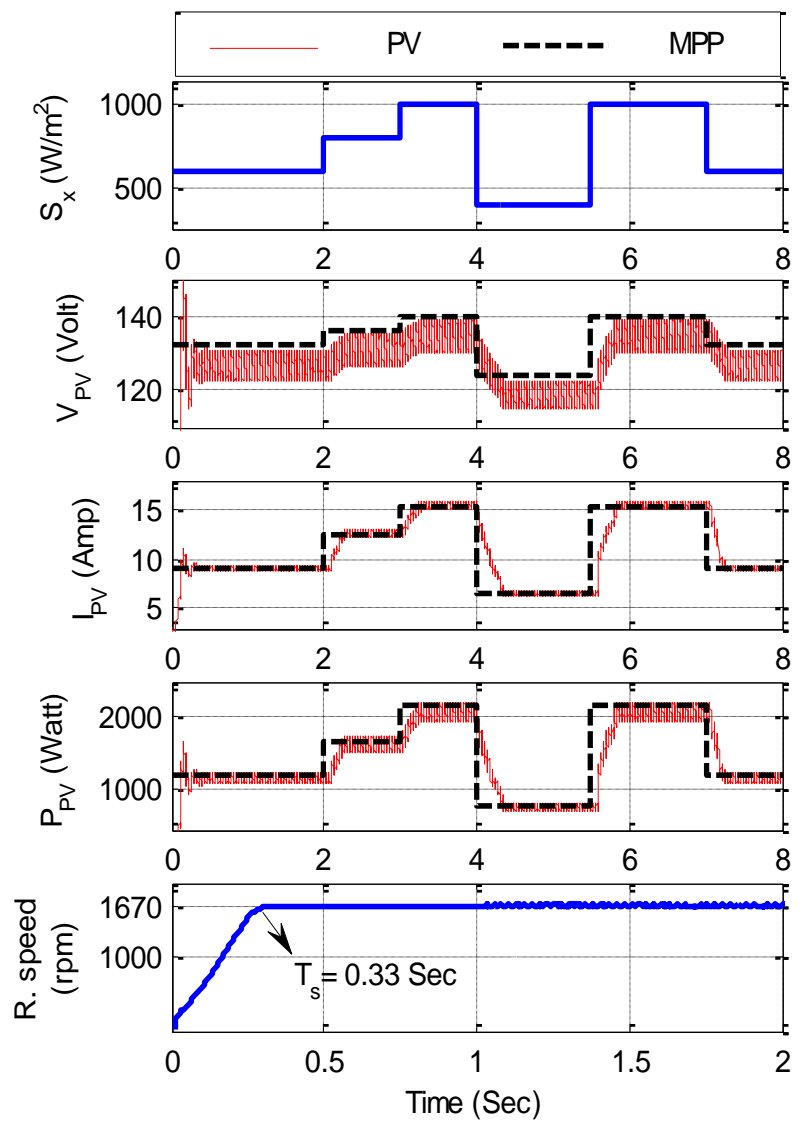

Fig 13: Dynamic response of IC MPPT assisted PV system under variable irradiation conditions

In Fig. 14, the dynamic response of FLC MPPT assisted PV system under variable irradiation levels from $400-1000 \mathrm{~W} / \mathrm{m}^{2}$ various steps. At time $0-2 \mathrm{Sec}$. the irradiations level is 600 $\mathrm{W} / \mathrm{m}^{2}$, the PV voltage, current and power are $128 \mathrm{~V}, 9.10 \mathrm{~A}$ and $1165 \mathrm{~W}$ respectively. It is observed that less time is taken to reach rated speed of IM in comparison other MPPT techniques assisted system is $0.26 \mathrm{Sec}$. Now the irradiation level is raised up to $800 \mathrm{~W} / \mathrm{m}^{2}$, so the resultant voltage, current and power increased gradually increased at $132 \mathrm{~V}, 12.53 \mathrm{~A}$ and $1654.35 \mathrm{~W}$. Now the irradiation level is increased to $1000 \mathrm{~W} / \mathrm{m}^{2}$ at $3 \mathrm{Sec}$, the voltage, current and power are $136 \mathrm{~V}$, $15.55 \mathrm{~A}$ and $2115 \mathrm{~W}$. Now the irradiation is decreased at $400 \mathrm{~W} / \mathrm{m}^{2}$, the voltage, current and power is calculated as $120 \mathrm{~V}, 6.48 \mathrm{~A}$ and $778.52 \mathrm{~W}$ respectively. Furthermore, the irradiation levels are repeated in various steps, so the transient response of voltage, current and power are same as previous satisfactory results. It is observed that the current is very close to its maximum value.

In Fig. 15, the dynamic response of ANN based MPPT assisted PV system under variable irradiation levels from 400$1000 \mathrm{~W} / \mathrm{m}^{2}$ various steps. At time $0-2 \mathrm{Sec}$. the irradiations level is $600 \mathrm{~W} / \mathrm{m}^{2}$, the PV voltage, current and power are $130 \mathrm{~V}, 9.060 \mathrm{~A}$ and $1177.90 \mathrm{~W}$ respectively. It is observed that less time is taken to reach rated speed of IM in comparison other MPPT techniques assisted system is $0.18 \mathrm{Sec}$. Now the 
irradiation level is raised up to $800 \mathrm{~W} / \mathrm{m}^{2}$, so the resultant voltage, current and power increased gradually increased at $134 \mathrm{~V}, 12.47 \mathrm{~A}$ and $1672.06 \mathrm{~W}$. Now the irradiation level is increased to $1000 \mathrm{~W} / \mathrm{m}^{2}$ at $3 \mathrm{Sec}$, the voltage, current and power are $138 \mathrm{~V}, 15.49 \mathrm{~A}$ and $2137.67 \mathrm{~W}$. Now the irradiation is decreased at $400 \mathrm{~W} / \mathrm{m}^{2}$, the voltage, current and power is
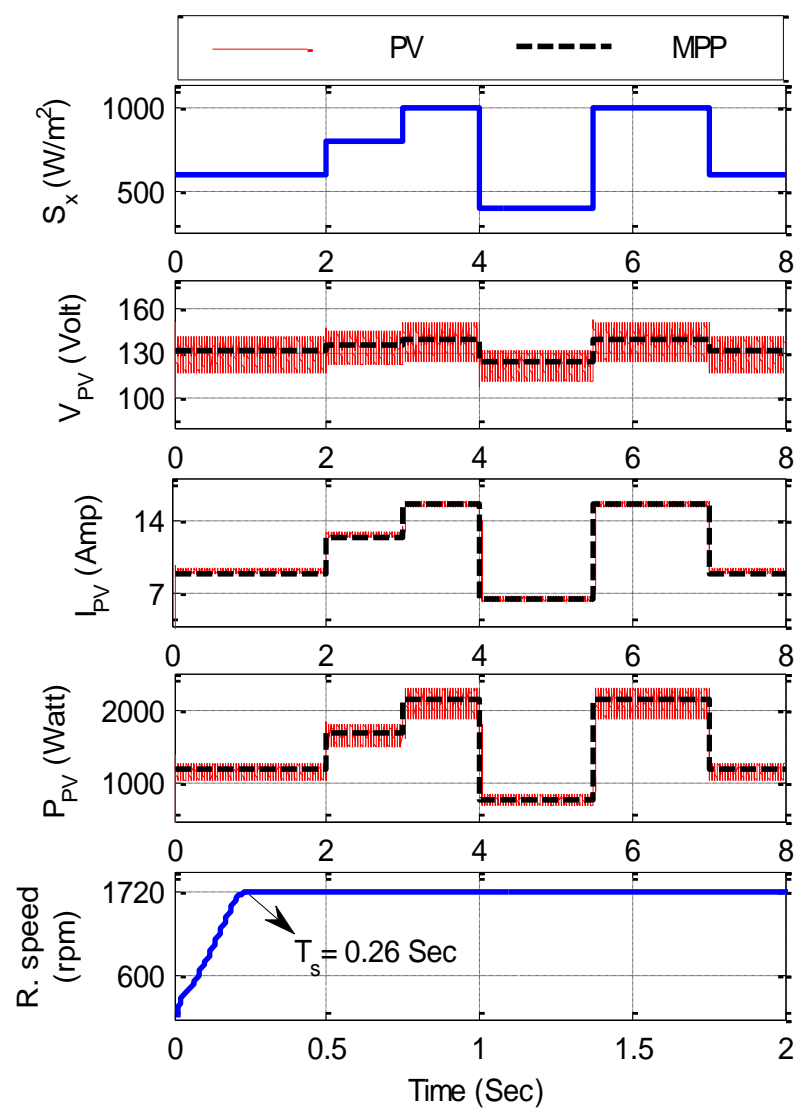

Fig 14: Dynamic response of FLC based MPPT assisted PV system under variable irradiation conditions calculated as $122 \mathrm{~V}, 6.449 \mathrm{~A}$ and $786.85 \mathrm{~W}$ respectively. Furthermore, the irradiation levels are repeated in various steps, so the transient response of voltage, current and power are same as previous satisfactory results. It is observed that the transient response is very close to its maximum value with minimum disturbances.
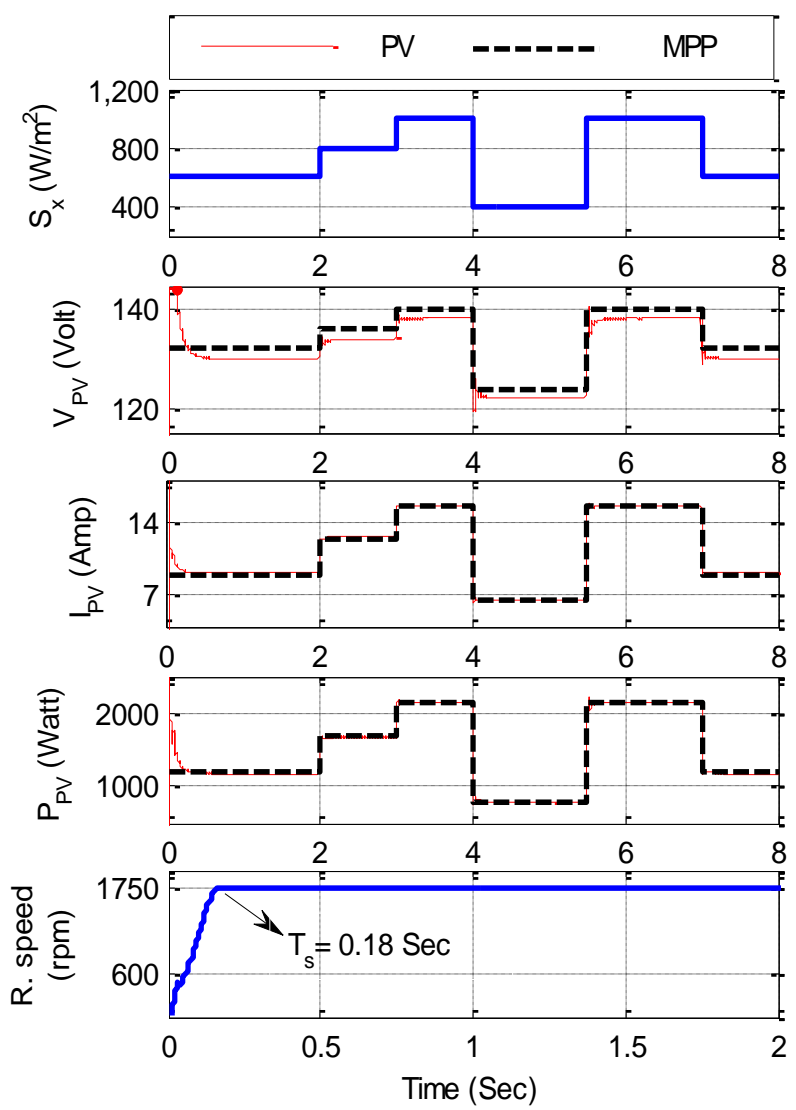

Fig.15: Dynamic response of ANN based MPPT assisted PV system under variable irradiation conditions

Table 2. Performance comparison of CVC, IC, P\&O, FLC and ANN based MPPT methods

\begin{tabular}{|c|c|c|c|c|c|c|}
\hline \multirow{2}{*}{\multicolumn{2}{|c|}{ Parameters }} & \multicolumn{5}{|c|}{ MPPT techniques } \\
\hline & & CVC & P\&O & IC & FLC & ANN \\
\hline \multicolumn{2}{|c|}{ Voltage $(\mathrm{V})$ at $\mathrm{G}=1000 \mathrm{~W} / \mathrm{m}^{2}$} & 131.1 & 133.03 & 133.96 & 136.01 & 138 \\
\hline \multicolumn{2}{|c|}{ Range of Voltage variation (V) } & $128-134$ & $132-136$ & $128-137$ & $132-139$ & $137-139$ \\
\hline \multicolumn{2}{|c|}{ Current (A) at $\mathrm{G}=1000 \mathrm{~W} / \mathrm{m}^{2}$} & 13.938 & 14.788 & 15.4 & 15.55 & 15.49 \\
\hline \multicolumn{2}{|c|}{ Range of Current variation (A) } & $13.5-14.5$ & $14.5-15$ & $14.9-15.9$ & $15.3-15.7$ & $15.4-15.6$ \\
\hline \multicolumn{2}{|c|}{ Power $(\mathrm{W})$ at $\mathrm{G}=1000 \mathrm{~W} / \mathrm{m}^{2}$} & 1827.272 & 1967.247 & 2062.984 & 2114.955 & 2137.62 \\
\hline \multicolumn{2}{|c|}{ Range of Power variation (W) } & $1754-1903$ & $1914-2040$ & $1907-2178.3$ & $2019.6-2182.3$ & $2109.8-2168.4$ \\
\hline \multicolumn{2}{|c|}{ Rotor Speed (rpm) } & 1650 & 1665 & 1670 & 1720 & 1750 \\
\hline \multicolumn{2}{|c|}{ Rotor Speed Settling Time (Sec) } & $0 . .51$ & 0.47 & 0.33 & 0.26 & 0.18 \\
\hline \multicolumn{2}{|l|}{ Efficiency $(\%)$} & 84.712 & 91.245 & 95.686 & 98.096 & 99.146 \\
\hline \multirow{3}{*}{$\begin{array}{c}\text { Rise Time } \\
\text { at } 5.5^{\text {th }} \mathrm{Sec} \\
(\mathrm{Sec})\end{array}$} & Voltage (V) & 0.57 & 039 & 0.31 & 0.16 & 0.009 \\
\hline & Current (A) & 0.58 & 0.30 & 0.26 & 0.13 & 0.007 \\
\hline & Power $(\mathrm{W})$ & 0.58 & 0.38 & 0.31 & 0.16 & 0.008 \\
\hline \multirow{3}{*}{$\begin{array}{l}\text { Fall Time } \\
\text { at } 4^{\text {th }} \mathrm{Sec} \\
(\mathrm{Sec})\end{array}$} & Voltage (V) & 0.52 & 0.34 & 0.26 & 0.19 & 0.011 \\
\hline & Current (A) & 0.51 & 0.32 & 0.27 & 0.15 & 0.009 \\
\hline & Power (W) & 0.52 & 0.34 & 0.27 & 0.19 & 0.011 \\
\hline
\end{tabular}




\section{CONCLUSION}

A study is carried out of 3-phase IM is powered by PV system, in this paper. Various types of MPPT methods such as CVC, IC, P\&O, FLC and ANN are considered to achieve the maximum power from PV system. In order to investigation the steady-state and transient analysis have been done. The performance of the considered MPPT methods is found satisfactory. Following are the silent points of this study:

- Mathematical modeling of PV system and subsequent MATLAB/Simulink model is developed.

- The performance of developed model is validated with the commercially available PV module (Suntech Power STP260-24/Vb).

- The effects of irradiation level have been studied and response of all the considered MPPT methods are observed in terms of output voltage, current, power, efficiency, rise time, fall time and steady state time of IM drive.

- A comparative study of all the MPPT methods is made and it is observed that ANN based MPPT method has highest tracking efficiency also observed to have good dynamic response.

- In future, some advance intelligent MPPT methods e.g. adaptive neuro-fuzzy, modified fuzzy (different size rule base) etc. can be adopted for performance investigations in this sequence.

\section{REFERENCES}

[1] Mekhilef, S., Saidur, S. V., Safari, A. 2010. A review on solar energy used in industries, Renewable and Sustainable Energy Reviews 15(4) 1777-1790.

[2] Kumar, P., Gupta, A., Pachauri, R. K., Chauhan, Y. K. 2015. Utilization of energy sources in hybrid PV/FC power assisted water pumping system, IEEE Conference on Computational Intelligence \& Communication Technology, 548-553.

[3] Solangi, K. H., Islam, M. R., Saidur, R., Rahim, N. A., Fayaz, S. 2011. A review on solar energy policy, Renewable and Sustainable Energy Reviews 15(4) 21492163.

[4] Pachauri, R., K., Chauhan, Y. K. 2014. Hybrid PV/FC stand alone green power generation: a perspective for Indian rural telecommunication systems, IEEE Conference on Issues and Challenges in Intelligent Computing Techniques, 807-815.

[5] Reisi, A. R., Moradi, M. H., Jamasb, S. 2013. Classification and comparison of maximum power point tracking techniques for photovoltaic system: a review, Renewable and Sustainable Energy Reviews 19 433-443.

[6] Mohanty, P., Bhuvaneswari, G., Dhaliwal, N. K. 2014. MATLAB based modeling to study the performance of different MPPT techniques used for solar PV system under various operating conditions, Renewable and Sustainable Energy Reviews 38 581-593.

[7] Ishaque, K., Salam, Z. 2013. A review of maximum power point tracking techniques of PV system for uniform and partial shading condition, Renewable and Sustainable Energy Reviews 19 475-488.
[8] Kamarzaman, N. A., Tan, C. W. A. 2014. Comprehensive review of maximum power point tracking algorithms for photovoltaic systems, Renewable and Sustainable Energy Reviews 37 585-598.

[9] Eldahab, Y. E. A., Saad, N. H., Zakry, A. 2014. Enhancing the maximum power point tracking techniques for photovoltaic systems, Renewable and Sustainable Energy Reviews 40 505-514.

[10] Faranda, R. Leva, S. 2006. Energy comparison of MPPT techniques for PV Systems, WSEAS Transactions on Power Systems 3(6) 2006.

[11] Shanthi, T., Vanmukhil, A. S. 2014. Fuzzy logic based MPPT control of hybrid power generation system, International Journal of Computer Applications 86(1) 3744.

[12] Esram, T., Chapman, P. L. 2007. Comparison of photovoltaic array maximum power point tracking techniques, IEEE Transactions on Energy Conversion 22(2) 439-449.

[13] Babaa, S. E., Armstrong, M., Pickert, V. 2014. Overview of maximum power point tracking methods for PV systems, Journal of Power and Energy Engineering 2 59-72.

[14] Sengar S. 2014. Maximum power point tracking algorithms for photovoltaic system: a review. International Review of Applied Engineering Research 4(2) $147-154$

[15] Dolara, A., Faranda, R., Leva, S. 2009. Energy comparison of seven MPPT techniques for PV systems. Journal of Electromagnetic Analysis \& Applications 3 152-162.

[16] Zainudin, H. N., Mekhilef, S. Comparison study of maximum power point tracker techniques for $\mathrm{PV}$ systems, International Middle East Power System Conference, 19-21.

[17] Patel, U. S., Sahu, D. Tirkey, D. 2013. Maximum power point tracking using Perturb \& Observe algorithm and compare with another algorithm, International Journal of Digital Application \& Contemporary Research 2(2) 1-8.

[18] Rawat, R., Chandel, S. S., 2013. Review of maximum power point tracking techniques for solar-photovoltaic systems, Energy Technology 1(8) 438-448.

[19] Sivachandran, P., Lakshmi, D., Janani, R. 2015. Survey of maximum power point tracking techniques in solar pv system under partial shading conditions, ARPN Journal of Engineering and Applied Sciences 10(1) 256-264.

[20] Pachauri, R, K., Chauhan, Y, K. 2014. Fuzzy logic controlled mppt assisted PV-FC power generation for water pumping system. IEEE Conference on Electrical, Electronics and Computer Science 1-6.

[21] Altas, I. H., Sharaf, A. M. 1992. A Fuzzy logic power tracking controller for a photovoltaic energy conversion scheme, Electric Power Systems Research Journal, 25(3) 227-238.

[22] Gupta, A., Kumar, P., Pachauri R. K., Chauhan, Y. K. 2014. Effect of environmental conditions on single and double diode PV system: a comparative study, International Journal of Renewable Energy Research 4(2) 849-858. 
[23] Pachauri, R. K., Chauhan, Y. K. 2014. Hydrogen generation/pressure enhancement using FC and ANN based MPPT assisted PV system, IEEE Conferences on Innovative Applications of Computational Intelligence on Power, Energy and Controls with their Impact on Humanity, 486-491.

[24] Specifications are available on: file:///C:/Users/Rupendra/Downloads/Suntech\%20STP\% 20260-24.pdf.

[25] Leedy, A. W., Guo, L., Aganah, K. A. 2012. A constant voltage MPPT method for a solar powered boost converter with DC motor load, IEEE South-east Conference, 1-6.

[26] Abdourraziq, M. A., Quassaid, M., Maaroufi, M., Abdourraziq, S. 2013. Modified P\&O MPPT method for photovoltaic systems, IEEE Conference on Renewable Energy Research and Applications, 728-733.

[27] Yang, Y., Zhou, K., Zou, Z. 2011. A modified P\&O MPPT control of photovoltaic systems, IEEE Conference on Electrical Machines and Systems, 1-3.

[28] Xiong, Y., Qian, S., Xu, J. 2012. Research on constant voltage with incremental conductance MPPT method, IEEE Conference on Power and Energy Engineering, 14.

\section{APPENDIX}

\begin{tabular}{|l|r|l|r|}
\hline \multicolumn{2}{|c|}{ Operating parameters } & Reference irradiation, $S_{c}$ & $1000 \mathrm{~W} / \mathrm{m}^{2}$ \\
\hline Curve fitting factor, $A$ & 1.4 & Variable irradiation, $S_{x}$ & $400-1000 \mathrm{~W} / \mathrm{m}^{2}$ \\
\hline Boltzman constant, $k$ & $1.38 \times 10^{-23} \mathrm{~J} / \mathrm{K}$ & Open circuit voltage coefficient, $\beta$ & 0.005 \\
\hline Cell temperature, $T_{c}$ & $45^{\circ} \mathrm{C}$ & Short circuit current coefficient, $\gamma$ & 0.07 \\
\hline Electron charge, $e$ & $1.602 \times 10^{-19}$ Coulombs & Ambient temperature, $T_{a}$ & $25^{\circ} \mathrm{C}$ \\
\hline Series resistance, $R_{s}$ & $0.037 \Omega$ & Variable temperature, $T_{x}$ & $10-50^{\circ} \mathrm{C}$ \\
\hline
\end{tabular}

